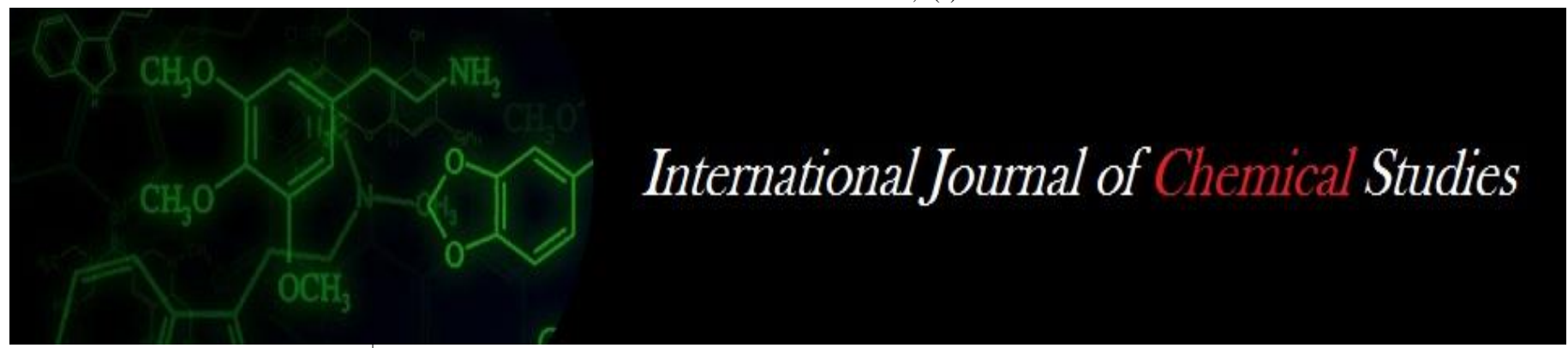

P-ISSN: 2349-8528

E-ISSN: 2321-4902

www.chemijournal.com

IJCS 2021; 9(1): 1324-1328

(C) 2021 IJCS

Received: 24-10-2020

Accepted: 30-11-2020

Anand Gouda

University of Agricultural

Sciences, CAE, GKVK,

Bengaluru, Karnataka, India

Rajashekarappa KS

University of Agricultural

Sciences, CAE, GKVK,

Bengaluru, Karnataka, India

Chikkaramappa $\mathbf{T}$

University of Agricultural

Sciences, CAE, GKVK,

Bengaluru, Karnataka, India

Devaraja K

University of Agricultural

Sciences, CAE, GKVK,

Bengaluru, Karnataka, India

Shivaraj S

University of Agricultural

Sciences, CAE, GKVK,

Bengaluru, Karnataka, India

Corresponding Author:

Anand Gouda

University of Agricultural

Sciences, CAE, GKVK,

Bengaluru, Karnataka, India

\section{Evaluation of Geo-morphological characteristics of Devanayakanahalli micro-watershed in Tumkur district of Karnataka}

\author{
Anand Gouda, Rajashekarappa KS, Chikkaramappa T, Devaraja K and \\ Shivaraj S
}

DOI: $\underline{\text { https://doi.org/10.22271/chemi.2021.v9.i1s.11406 }}$

\begin{abstract}
Devanayakanahalli micro-watershed lies between $13^{\circ} 4^{\prime} 54^{\prime \prime}$ to $13^{\circ} 6^{\prime} 29^{\prime \prime} \mathrm{N}$ latitude and $76^{\circ} 39^{\prime} 43^{\prime \prime}$ to $76^{\circ} 41^{\prime} 17 "$ E longitude in Tumkur district of Karnataka. The drainage networks of micro-watershed were delineated from the Survey of India topographical map of 1:50,000 scale. ArcGIS software was used for evaluation of linear, areal and relief aspects of the micro-watershed. The present study reveals that, drainage pattern of the study area is dendritic with trunk order 3. The watershed area, perimeter, maximum length and width of the watershed were $453 \mathrm{ha}, 10.10 \mathrm{~km}, 3.68 \mathrm{~km}$ and $1.23 \mathrm{~km}$ respectively. The mean value of bifurcation ratio is 2.20 , the micro-watershed has been suffered less structural disturbance and drainage pattern has not been distorted. The value of drainage density is $2.30 \mathrm{~km} \mathrm{~km}^{-2}$ which indicated that, the region is having permeable subsoil material and good vegetative cover. The value of form factor indicates micro-watershed is approaching towards elongated shape of watershed. The present study reveales that, GIS based approach in evaluation of geo-morphological characteristics is more appropriate than conventional techniques. Over all study suggests that the micro-watershed should be treated with soil and water conservation measures.
\end{abstract}

Keywords: ArcGIS, microwatershed, drainage density, form factor, geo-morphology

\section{Introduction}

Morphometry is the measurement and mathematical analysis of the configuration of the earth's surface, shape and dimension of its landforms (Agarwal, 1998) ${ }^{[1]}$. Horton (1940) ${ }^{[4]}$ and Strahler (1950) ${ }^{[16]}$ first initiated Morphometric studies in the field of hydrology. The morphometric analysis of the drainage basin and channel network play an important role in understanding the geo hydrological behaviour of drainage basin and expresses the prevailing climate, geology, geomorphology, structural antecedents of the catchment. The relationship among various drainage parameters and the aforesaid factors are well recognized by Horton (1945) ${ }^{[5]}$, Strahler (1950) ${ }^{[16]}$, Sreenivasa et al. (2016) ${ }^{[17]}$ and Pande et al. (2017) ${ }^{[12]}$. The drainage basin analysis is important in any hydrological investigation for assessment of groundwater potential, groundwater management, pedology and environmental assessment. Hydrologists and geo-morphologists have recognized that, certain relations are almost important between runoff characteristics, geographic and geomorphic characteristics of drainage basin systems.

The assessment of hydrological characteristics of a drainage basin is a mandate for any basin management scheme. It involves a detailed morphometric analysis viz., basin size, shape, slope of drainage area, drainage density, size and length of the tributaries. Drainage basins are the fundamental units of the fluvial landscape and a great amount of research has focused on their geometric characteristics, which include the topology of the stream networks and quantitative description of drainage texture, pattern, shape and relief characteristics. Morphometric analysis of a watershed provides a quantitative description of the drainage system, which is an important aspect of the characterization of watersheds (Strahler, 1964) ${ }^{[19]}$. 


\section{Material and Methods}

The present study was taken up in Devanayakanahalli microwatershed located in Turvekeretaluk of Tumkur district, Karnataka state (Fig.1) and having total area of 453 ha which lies between $76^{\circ} 39^{\prime} 43^{\prime \prime}$ to $76^{\circ} 41^{\prime} 17^{\prime \prime}$ E longitudes and $13^{\circ} 4^{\prime}$ $54 "$ to $13^{\circ} 6^{\prime} 29^{\prime \prime} \mathrm{N}$ latitudes with an average altitude of 450 $800 \mathrm{~m}$ above MSL and located in the Southern part of Tumkur district. It is falling under the Survey of India toposheet of D43Q12 (1:50,000).

The geo-morphological characteristics of the micro-watershed were determined by digitizing the drainage networks (Fig.2) in SoI toposheet using Arc GIS (Arc map version 10.2.2) software and subsequent cleaning, editing and assigning topology produced a database in terms of linear, aerial and relief aspects of the watershed. The first step in quantitative analysis of drainage basin is designation of stream order. In the present study, for ordering of streams, Strahler's ordering system was adopted. The parameters computed in the present paper using GIS technique includes stream number, stream order, stream length, bifurcation ratio, stream length ratio, drainage density, drainage texture, stream frequency, form factor, circulatory ratio, elongation ratio, maximum watershed relief, relief ratio and ruggedness number were evaluated with established mathematical formulae represented in the Table 1.

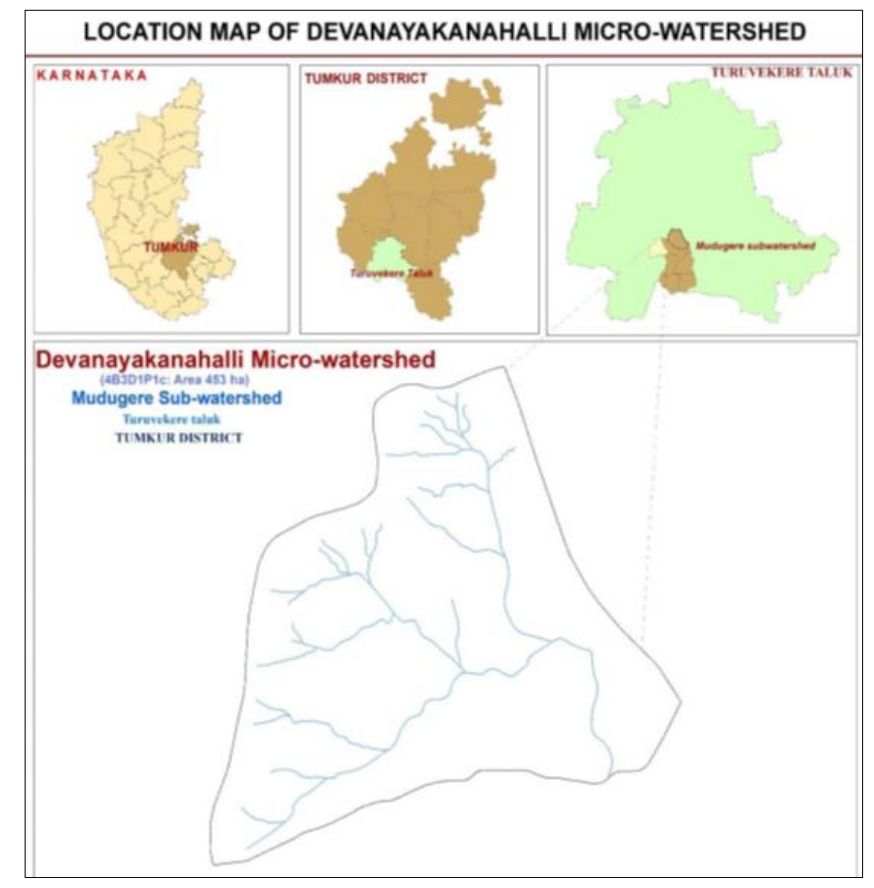

Fig 1: Location map of study area

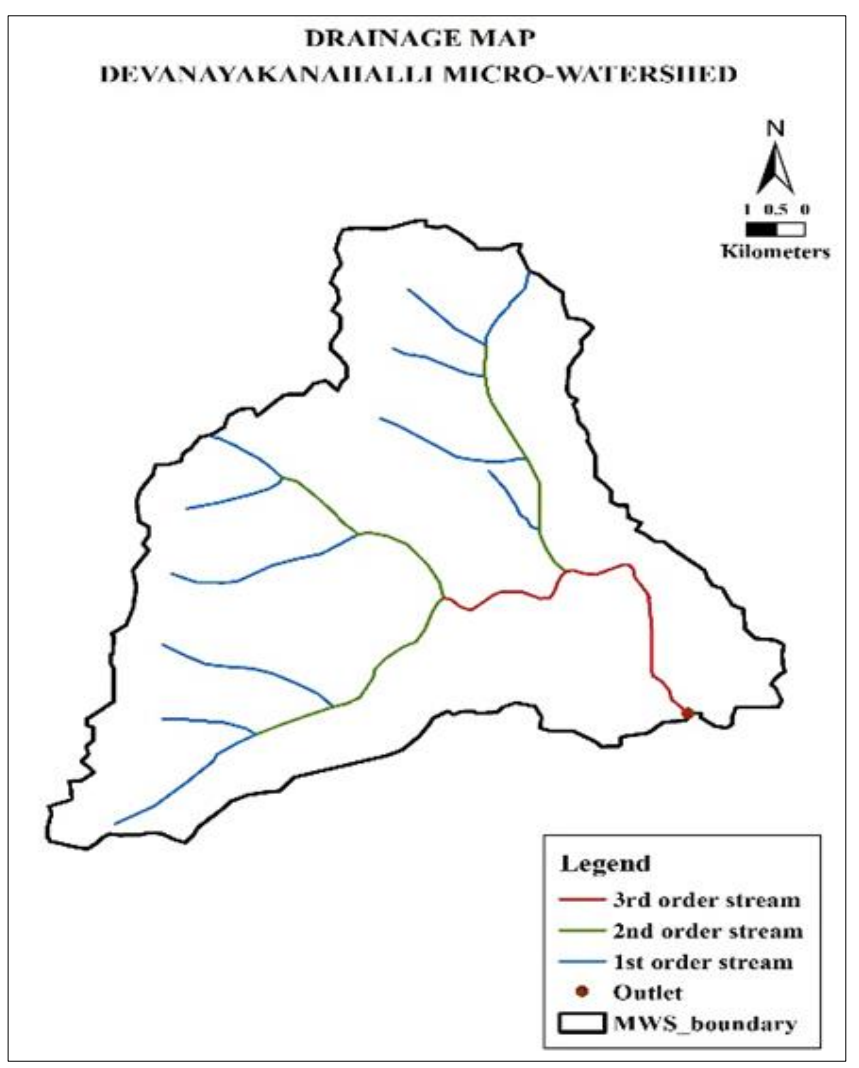

Fig 2: Drainage map of Devanayanakanahalli micro-watershed 
Table 1: Formulae adopted for evaluation of geo-morphological characteristics

\begin{tabular}{|c|c|c|c|c|}
\hline Sl. No. & Parameters & & Formulae & References \\
\hline 1 & Stream order $(\mathrm{U})$ & Hierachical rank & 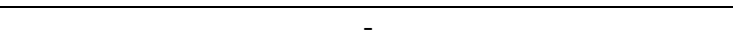 & Strahler (1964) ${ }^{[19]}$ \\
\hline 2 & Stream length $\left(\mathrm{L}_{\mathrm{u}}\right), \mathrm{km}$ & Length of the stream & - & Horton (1945) ${ }^{[5]}$ \\
\hline 3 & Mean stream length $\left(\overline{\mathrm{L}}_{\mathrm{u}}\right), \mathrm{km}$ & $\overline{\mathrm{L}}_{\mathrm{u}}=\frac{\sum_{\mathrm{i}=1}^{\mathrm{N}} \mathrm{L}_{\mathrm{u}}}{\mathrm{N}_{\mathrm{u}}}$ & $\begin{array}{c}\mathrm{L}_{\mathrm{u}}=\text { Cumulative length of all streams of order } \mathrm{u}(\mathrm{km}) \\
\mathrm{N}_{\mathrm{u}}=\text { Number of streams of the given order } \mathrm{u}\end{array}$ & Strahler $(1964)^{[19]}$ \\
\hline 4 & Bifurcation ratio $\left(\mathrm{R}_{\mathrm{b}}\right)$ & $\mathrm{R}_{\mathrm{b}}=\frac{\mathrm{N}_{\mathrm{u}}}{\mathrm{N}_{\mathrm{u}+1}}$ & $\begin{array}{c}\mathrm{N}_{\mathrm{u}}=\text { Number of stream segments of order } \mathrm{u} \\
\mathrm{N}_{\mathrm{u}+1}=\text { Number of stream segments of next higher order }\end{array}$ & Schuum (1956) \\
\hline 5 & Stream length ratio $\left(\mathrm{R}_{\mathrm{L}}\right)$ & $\mathrm{R}_{\mathrm{L}}=\frac{\overline{\mathrm{L}}_{\mathrm{u}}}{\overline{\mathrm{L}}_{\mathrm{u}-1}}$ & $\begin{array}{c}\overline{\mathrm{L}}_{\mathrm{u}}=\text { Mean stream length }(\mathrm{km}) \\
\overline{\mathrm{L}}_{\mathrm{u}-1}=\text { Mean stream length of next lower order }(\mathrm{km})\end{array}$ & Horton $(1945)^{[5]}$ \\
\hline 6 & $\begin{array}{c}\text { Drainage density }\left(\mathrm{D}_{\mathrm{d}}\right), \mathrm{km} \\
\mathrm{km}^{-2}\end{array}$ & $\mathrm{D}_{\mathrm{d}}=\frac{\mathrm{L}}{\mathrm{A}}$ & $\begin{array}{c}\mathrm{L}=\text { Total length of streams of all order }(\mathrm{km}) \\
\mathrm{A}=\text { Total area of watershed }\left(\mathrm{km}^{2}\right)\end{array}$ & Horton (1932) \\
\hline 7 & Drainage texture $\left(D_{t}\right)$ & $\mathrm{D}_{\mathrm{t}}=\frac{\mathrm{N}}{\mathrm{P}}$ & $\begin{array}{c}\mathrm{N}_{1}=\text { Total Number of stream segments of all orders } \\
\mathrm{P}=\text { Basin perimeter }(\mathrm{km})\end{array}$ & Smith $(1950)^{[16]}$ \\
\hline 8 & Stream frequency $(\mathrm{F})$ & $\mathrm{F}=\frac{\mathrm{N}}{\mathrm{A}}$ & $\begin{array}{c}\mathrm{N}=\text { Total number of stream segments of all orders } \\
\mathrm{A}=\text { Basin area }\left(\mathrm{km}^{2}\right)\end{array}$ & Horton (1945) ${ }^{[5]}$ \\
\hline 9 & Form factor $\left(\mathrm{R}_{\mathrm{f}}\right)$ & $\mathrm{R}_{\mathrm{f}}=\frac{\mathrm{A}}{\left(\mathrm{L}_{\mathrm{b}}\right)^{2}}$ & $\begin{array}{c}\mathrm{A}=\text { Area of watershed }\left(\mathrm{km}^{2}\right) \\
\mathrm{L}_{\mathrm{b}}=\text { Length of basin }(\mathrm{km})\end{array}$ & Horton $(1945)^{[5]}$ \\
\hline 10 & Elongation ratio $\left(\mathrm{R}_{\mathrm{e}}\right)$ & $\mathrm{R}_{\mathrm{e}}=\left(\frac{2}{\mathrm{~L}_{\mathrm{b}}}\right) \sqrt{\frac{\mathrm{A}}{\pi}}$ & $\begin{aligned} \mathrm{L}_{\mathrm{b}} & =\text { Basin length }(\mathrm{km}) \\
\mathrm{A} & =\text { Basin area }\left(\mathrm{km}^{2}\right)\end{aligned}$ & Strahler (1964) ${ }^{[19]}$ \\
\hline 11 & Circulatory ratio $\left(\mathrm{R}_{\mathrm{c}}\right)$ & $R_{c}=\frac{4 \pi A}{\left(A_{C}\right)^{2}}$ & $\begin{array}{c}\mathrm{A}=\text { Area of watershed, }\left(\mathrm{km}^{2}\right) \\
\mathrm{A}_{\mathrm{c}}=\text { Perimeter of the watershed }(\mathrm{km})\end{array}$ & Schuum (1956) \\
\hline 12 & $\begin{array}{l}\text { Length of over land flow } \\
\left(\mathrm{Lg}_{\mathrm{g}}\right), \mathrm{km}\end{array}$ & $\mathrm{L}_{\mathrm{g}}=\frac{1}{2 \mathrm{D}_{\mathrm{d}}}$ & $\mathrm{D}_{\mathrm{d}}=$ Drainage density $\left(\mathrm{km} \mathrm{km}^{-2}\right)$ & Horton $(1945)^{[5]}$ \\
\hline 13 & $\begin{array}{l}\text { Maximum watershed relief } \\
(\mathrm{H}), \mathrm{m}\end{array}$ & $\mathrm{H}=\mathrm{h}_{\max }-\mathrm{h}_{\min }$ & $\begin{array}{c}\mathrm{h}_{\max }=\text { Elevation of highest elevated point }(\mathrm{m}) \\
\mathrm{h}_{\min }=\text { Elevation of lowest elevated point }(\mathrm{m})\end{array}$ & Schuum (1956) \\
\hline 14 & Relief ratio $\left(\mathrm{R}_{\mathrm{r}}\right)$ & $\mathrm{R}_{\mathrm{r}}=\frac{\mathrm{H}}{\mathrm{L}_{\mathrm{b}}}$ & $\begin{array}{c}\mathrm{H}=\text { Maximum watershed relief }(\mathrm{m}) \\
\mathrm{L}_{b}=\text { Maximum watershed length }(\mathrm{km})\end{array}$ & Schuum (1956) \\
\hline 15 & Relative relief $\left(\mathrm{R}_{\mathrm{R}}\right), \%$ & $\mathrm{R}_{\mathrm{R}}=100 \frac{\mathrm{H}}{\mathrm{L}_{\mathrm{p}}}$ & $\begin{array}{c}\mathrm{H}=\text { Watershed relief }(\mathrm{m}) \\
\mathrm{L}_{\mathrm{p}}=\text { Length of perimeter }(\mathrm{m})\end{array}$ & Schuum (1956) \\
\hline 16 & Rugdness number $\left(\mathrm{R}_{\mathrm{n}}\right)$ & $\mathrm{R}_{\mathrm{n}}=\frac{\mathrm{HD}_{\mathrm{d}}}{1000}$ & $\begin{array}{c}\mathrm{H}=\text { Maximum watershed relief }(\mathrm{m}) \\
\mathrm{D}_{\mathrm{d}}=\text { Drainage density }\left(\mathrm{km} \mathrm{km}^{-2}\right)\end{array}$ & Melton (1957) ${ }^{[10]}$ \\
\hline 17 & $\begin{array}{l}\text { Time of Concentration }\left(\mathrm{T}_{\mathrm{c}}\right) \\
\min \end{array}$ & $\mathrm{T}_{\mathrm{c}}=0.0195 \mathrm{~L}^{0.77} \mathrm{~S}^{-0.385}$ & $\begin{array}{c}\mathrm{L}=\text { Length of watershed from remote point to outlet }(\mathrm{m}) \\
\mathrm{S}=\text { Slope of the catchment }(\mathrm{m} / \mathrm{m})\end{array}$ & Kirpich $(1940)^{[6]}$ \\
\hline
\end{tabular}

\section{Results and Discussion}

The geomorphological analysis and measurements were made from the digitized drainage pattern map of the Devanayakanahalli micro-watershed. Digitized drainage pattern was shown in Fig.2.

\section{Linear aspects of drainage network}

In this chapter, stream order, stream number, basin length, average basin width, stream length, mean stream length, bifurcation ratio and stream length ratio were analysed. After analysis it was found that, the micro-watershed was of $3^{\text {rd }}$ order trunk stream and drainage pattern was dendritic which indicates the homogeneity in texture and lack of structural control. Maximum length and basin width of micro-watershed was found to be $3.68 \mathrm{~km}$ and $1.23 \mathrm{~km}$ respectively. The number of streams for $1^{\text {st }}, 2^{\text {nd }}$ and $3^{\text {rd }}$ order streams were found to be 11, 3 and 1 respectively. The values of cumulative stream length for $1^{\text {st }}, 2^{\text {nd }}$ and $3^{\text {rd }}$ order streams were found to be 5.60, 3.11 and $1.68 \mathrm{~km}$ respectively (Table 2). The stream length of different orders and respective mean stream lengths were found out by digitizing the stream networks using ArcGIS software.

Table 2: Stream order and its mean stream lengths of Devanayakanahalli micro-watershed

\begin{tabular}{|c|c|c|c|c|}
\hline \multirow{2}{*}{ Parameters } & \multicolumn{3}{|c|}{ Stream order (U) } & \multirow{2}{*}{ Total } \\
\cline { 2 - 5 } & I & II & III & 15 \\
\hline No. of streams & 11 & 3 & 1 & 10.39 \\
\hline Cumulative stream length $(\mathrm{km})$ & 5.60 & 3.11 & 1.68 & 3.21 \\
\hline Mean stream length $(\mathrm{km})$ & 0.50 & 1.03 & 1.68 & \\
\hline
\end{tabular}

The other important properties of linear aspects of drainage network is bifurcation ratio $\left(\mathrm{R}_{\mathrm{b}}\right)$, which reflects about geological and tectonic characteristics of the watershed. The bifurcation ratio $\left(\mathrm{R}_{\mathrm{b}}\right)$ values of $1^{\text {st }}$ to $2^{\text {nd }}$ and $2^{\text {nd }}$ to $3^{\text {rd }}$ stream was found to be 3.66 and 3.00 respectively (Table 3 ). The mean value of bifurcation ratio was found to be 2.22 . Thus, the bifurcation ratio value was low indicates that, microwatershed had suffered less structural disturbance and drainage pattern had not been distorted by structural disturbance (Nag, 1998) ${ }^{[11]}$. The values of stream length ratio $\left(\mathrm{R}_{\mathrm{L}}\right)$ for $2^{\text {nd }}$ to $1^{\text {st }}$ and $3^{\text {rd }}$ to $2^{\text {nd }}$ order streams were found to be 2.06 and 1.63 respectively (Table 3 ). Change in stream length ratio from one order to another order indicating their late youth stage of geomorphic development (Singh and Singh 1997) ${ }^{[15]}$. The variation in stream length ratio was due to change in slope and topography. 
Table 3: Bifurcation ratio and stream length ratio of Devanayakanahalli micro-watershed

\begin{tabular}{|c|c|c|}
\hline Stream order $(\mathbf{U})$ & Bifurcation ratio $\left(\mathbf{R}_{\mathbf{b}}\right)$ & Stream length ratio $\left(\mathbf{R}_{\mathbf{L}}\right)$ \\
\hline I & 3.66 & - \\
\hline II & 3.00 & 2.06 \\
\hline III & - & 1.63 \\
\hline Mean & 2.22 & 1.23 \\
\hline
\end{tabular}

\section{Aerial aspects of drainage network}

Aerial aspects of drainage network include measurement of aerial elements viz., drainage area, form factor, drainage density, drainage texture, stream frequency, circulatory ratio, elongation ratio and length of overland flows were represented in a systematic way. From the study it was revealed that, the value of form factor $\left(R_{f}\right)$ was found to be 0.33 (Table 4). Since the value of form factor was less than 0.78 , it indicates an elongated shape of the micro-watershed (Horton, 1932). An elongated basin with low form factor shows flatter peak flow for longer duration (Mahadevaswamy et al., 2011) ${ }^{[8]}$.

The value of drainage density $\left(\mathrm{D}_{\mathrm{d}}\right)$ was found to be $2.30 \mathrm{~km}$ $\mathrm{km}^{-2}$ (Table 4) which falls in the range of 2.0 to $2.5 \mathrm{~km} \mathrm{~km}^{-2}$ and indicated that the region is having permeable subsoil material and good vegetation cover (Mallik et al., 2011) ${ }^{[9]}$. The value of drainage texture $\left(D_{t}\right)$ was found to be $1.48 \mathrm{~km}^{-1}$ (Table 4) which indicates about the coarse drainage texture of the micro-watershed (Smith, 1950) ${ }^{[16]}$. The coarse drainage texture indicates a good permeability of sub surface material and infiltration and lower runoff rate (Hajam et al., 2013) ${ }^{[3]}$.

The value of stream frequency was found to be $3.31 \mathrm{~km}^{-2}$ which indicates, high discharge carrying capacity and greater erosion hazard (Kuldeep and Upasan, 2011) ${ }^{[7]}$. The lesser the values of drainage density and stream frequency indicates the runoff basin is slower and chances of flooding may be very rare. Circulatory ratio $\left(R_{c}\right)$ and elongation ratio $\left(R_{e}\right)$ were found to be 0.55 and 0.64 respectively (Table 4 ). The greater elongation ratio than circulatory ratio results in elongated formation of watershed than circular watershed. In the present study, the value of elongation ratio (0.64) indicates elongated shaped micro-watershed.

The length of over land flow is the length of water over the ground before it gets concentrated into definite stream channels and is equal to half of drainage density (Horton, 1945) ${ }^{[5]}$. Length of overland flow relates inversely to the average channel slope. In the present study, the lower values of length of overland flow due to low drainage density and which confirm with Horton's (1945) ${ }^{[5]}$.

Table 4: Aerial aspects of Devanayakanahalli micro-watershed

\begin{tabular}{|c|c|c|}
\hline Sl. No. & Aerial aspects & Value \\
\hline 1 & Drainage area $(\mathrm{A}), \mathrm{ha}$ & 453 \\
\hline 2 & Form factor $\left(\mathrm{R}_{\mathrm{f}}\right)$ & 0.33 \\
\hline 3 & Drainage density $\left(\mathrm{D}_{\mathrm{d}}\right), \mathrm{km} \mathrm{km}^{-2}$ & 2.30 \\
\hline 4 & Drainage texture $\left(\mathrm{D}_{\mathrm{t}}\right), \mathrm{km}^{-1}$ & 1.48 \\
\hline 5 & Stream frequency $(\mathrm{F}), \mathrm{km}^{-2}$ & 3.31 \\
\hline 6 & Circulatory ratio $\left(\mathrm{R}_{\mathrm{c}}\right)$ & 0.55 \\
\hline 7 & Elongation ratio $\left(\mathrm{R}_{\mathrm{e}}\right)$ & 0.64 \\
\hline 8 & Length of overland flow $\left(\mathrm{L}_{\mathrm{g}}\right), \mathrm{km}$ & 0.21 \\
\hline
\end{tabular}

\section{Relief aspects of drainage network}

Relief aspects of drainage network for Devanayakanahalli micro-watershed were calculated and represented in the Table 5. The estimated value of Maximum watershed relief $(\mathrm{H})$, Relative relief $\left(R_{R}\right)$ and Relief ratio $\left(R_{r}\right)$ were found to be 66 $\mathrm{m}, 0.006$ and 0.017 respectively. The lower value of relief ratio indicates a presence of basement rocks that were exposed in the form of small ridges and mounds with lower degree of slope (Praveen et al., 2012) ${ }^{[13]}$. Addition to these properties, ruggedness number value was computed and it was found to be 0.15 . The lower value of ruggedness number indicates that, the area was less prone to soil erosion and had an intrinsic structural complexity in association with relief and drainage density (Guha, 2015) ${ }^{[2]}$. Time of concentration directly influences on runoff generation from the watershed. In the present study the time of concentration is $54 \mathrm{~min}$ and it indicates more time is required for water to travel from the most distant part of watershed to its outlet.

Table 5: Relief aspects of Devanayakanahalli micro-watershed

\begin{tabular}{|c|c|c|}
\hline Sl. No. & Relief parameters & Value \\
\hline 1 & Maximum watershed relief $(H)$ in $\mathrm{m}$ & 66 \\
\hline 2 & Relative relief $\left(\mathrm{R}_{\mathrm{R}}\right)$ & 0.006 \\
\hline 3 & Relief ratio $\left(\mathrm{R}_{\mathrm{r}}\right)$ & 0.017 \\
\hline 4 & Ruggedness number $\left(\mathrm{R}_{\mathrm{n}}\right)$ & 0.15 \\
\hline 5 & Time of concentration $\left(\mathrm{T}_{\mathrm{c}}\right)$ in min & 54 \\
\hline
\end{tabular}

\section{Conclusion}

- From the study it was revealed that, Devanayakanahalli micro-watershed had $3^{\text {rd }}$ order trunk stream and drainage pattern was dendritic which indicates the homogeneity in texture and lack of structural control.

- The values of drainage density, drainage texture and texture ratio were found to be $2.30 \mathrm{~km} \mathrm{~km}^{-2}, 1.48 \mathrm{~km}^{-1}$ and $1.08 \mathrm{~km}^{-1}$ respectively and these values indicates that micro-watershed has permeable sub soil geology and good vegetation cover.

- From the relief aspect it was found that, time of concentration is $54 \mathrm{~min}$. It indicates more time is required for water to travel from the most distant part of microwatershed to outlet and leads to low runoff due to permeable soils and gentle slope in study area.

- The use of GIS can make the cumbersome geomorphological analysis as an easy task as compared to traditional methods. It saves time and helpful in planning of resource conservation techniques in the watershed area for sustainable development. This study indicates that, systematic analysis of morphometric parameters using GIS can provide significant value in understanding basin hydrological characteristics for watershed planning and management.

\section{References}

1. Agarwal CS. Study of drainage pattern through aerial data in Naugarh area of Varanasi district, UP. J Ind. Soc. Remote Sens 1998;26(4):169-175.

2. Guha S. Mathematical analysis of Solani Watershed, North India. Int. J Geomat. Geosci 2015;6(2):1512-1529.

3. Hajam RA, Hamid A, Bhat S. Application of morphometric analysis for geo hydrological studies using geo-spatial technology: A case study of Vishav drainage basin. Hydrology Curr. Res 2013;4(3):2-12.

4. Horton RE. An approach toward a physical interpretation of infiltration-capacity. Soil Sci. Soc. American J 1940;5:399-417.

5. Horton RE. Erosional development of streams and their drainage basins; hydro physical approach to quantitative morphology. Geological soci. America bulletin 1945;56(3):275-370.

6. Kirpich TP. Time of Concentration of Small Agricultural Watersheds. J Civil Engg 1940;10(6):362. 
7. Kuldeep P, Upasana P. Quantitative Morphometric Analysis of a Watershed of Yamuna Basin, India using Aster (DEM) Data and GIS. Int. J Geomat. Geosci 2011;2(1):248-269.

8. Mahadevaswamy G, Nagaraju D, Siddalingamurthy S, Lone MS, Nagesh PC, Rao K. Morphometric analysis of Nanjangudtaluk, Mysore District, Karnataka, India, using GIS techniques. Int. J Geomat. Geosci 2011;1(4):721734.

9. Mallik MI, Bhat MS, Kuchay NA. Watershed based drainage morphometric analysis of Lidder catchment in Kashmir valley using GIS. Recent Res. Sci. Tech 2011;3(4):118-126.

10. Melton MA. An analysis of the relations among elements of climate, surface properties and geomorphology (No. CU-TR-11). Columbia Univ. New York 1957.

11. Nag SK. Morphometric analysis using remote sensing techniques in the Chaka sub-basin, Purulia district, West Bengal. J Indian Soc. Remote Sensing 1998;26(1):69-76.

12. Pande CB, Patode RS, Moharir KN. Morphometric Analysis Using Remote Sensing and GIS Techniques: A Case Study of Devdari Watershed, Patur Tq., Akola District, Maharashtra. Trends Biosci 2017;10(1):219-223.

13. Praveen R, Kumar U, Singh VK. Geomorphometric characterization of upper south Koel basin, Jharkhand: A remote sensing \& GIS approach. J Water Res. Prot 2012;4(12):1042-1050.

14. Schumm SA. Evaluation of drainage systems and slopes in bad land at Parth Ambo, New Jersy. Bulletin Geological Soc America 1954;67:597-646.

15. Singh S, Singh MC. Morphometric analysis of Kanhar river basin. National Geographical J India 1997;43(1):3143.

16. Smith. Standards for grading textures of erosional topography. American J Soc 1950;248:655-668.

17. Sreenivasa A, Asode AN, Murgod S. Drainage evaluation of Doddhalla sub basin, Karnataka, India using GIS. Int. J Res. App. Sci. Engg. Tech 2016;4(3):89-93.

18. Strahler AN. Equilibrium theory of erosional slopes approached by frequency distribution analysis. American J Sci 1950;248:673-696.

19. Strahler AN. Quantitative geomorphology of drainage basin and channel networks. Handbook applied hydrology 1964;23:543-552. 